\title{
Capital Structure, Financial Flexibility and Real Options
}

\author{
Andreas Rams \\ University of Latvia / FernUniversität Hagen
}

\begin{abstract}
The field of research on capital structure has existed for six decades until today. It started with the initiative paper from Modigliani / Miller in 1958. Since then, there has been a lively debate on the issue of optimal capital structure, which has taken place in both theory and practice of corporate finance. The optimal capital structure is defined as the one that increases or even maximizes a company's - relative - profitability and indirectly its value.

Very roughly, the capital structure debate divides into two parts. The one of them mainly concentrates on capital costs, risks and other parameters and their potential effect on the value of a company. The other part of the debate examines the potential interaction between the capital structure and the decisions regarding real investments and then the following effects on the earnings and value of a company.

This paper intends to deal primarily with the second part of the capital structure debate. It follows the idea of investigating financial flexibility as a potential cause of higher company profitability and value and intends to investigate this view using the real options approach. The real option theory is an independent field of research. It follows the theoretical approach of understanding investment opportunities - under special circumstances - as real options that are - at least partly - comparable to financial options. This field of research started with an initiative paper of Myers in 1977.

The topic of financial flexibility combines the theory of capital structure with the theory of real options. Following this promising connection, this paper first discusses the consideration of financial flexibility as a real option theoretically and then illustrates it by employing a rather simple empirical approach. A relatively new and alternative understanding of the definition of the capital structure is also applied. Resulting, the
\end{abstract}


analysis of this paper shows that companies that remain financially flexible - by keeping their debt capacity open - tend to show relatively better performance figures.

Keywords: Capital structure, financial flexibility, real options, debt capacity, strategic finance.

\section{Introduction}

The aim of this paper is to analyse the possible value of financial flexibility for the management of companies. For this purpose, the two independent research areas capital structure theory and real option theory are linked together. It will be shown that both approaches together contribute quite well to the analysis of the topic of financial flexibility.

The debate about the potentially optimal capital structure of companies is of great interest to financial theory and practice. Roughly, two different questions are examined:

(1) Is there a specific capital structure that lowers the cost of capital and increases the value of a company - and what is it?

(2) Is there an interaction between the capital structure decision on the one hand and the real investment decisions of a company - and what is the relationship between the two?

This paper aims at the question whether the financial capital structure of companies may show interactions with or have an influence on their real world, their investments, their performance, the decisions of their management and resulting the company value. While discussing this question, the capital structure shall not simply be understood as a pure relation of debt to equity by taking into account the practical point of view of the financial managers of companies. In concrete terms, key figures are used here which are also used in the rating analysis of companies and as debt covenants, too. This introductory paper then practically employs only one respective financial indicator: the debt / EBITDA ratio, which is widely used in practice. 


\section{HPSCONF}

\section{October 19 - 21, 2018 - Munich, Germany}

Following the approach of the real option theory, the value contribution that can result from financial flexibility is examined in more detail. The value of a real option generally lies in the fact that a company in a situation of high uncertainty may have the possibility - or right - to wait with an investment decision and thus keep its respective option open for a certain period. The price for this holding the option open can be a limited cost, which - if the option will not be exercised - would result in a limited loss. Since a company then normally also needs financial resources to exercise the open real option, real options in in general themselves appear to be linked to financial real options. Following this idea, this paper analyses the relationship between "keeping financial real options open" and the performance of companies.

This first chapter provides a condensed overview of the approach and objectives of this paper. Subsequently, the second chapter offers a combined overview of the theory and literature on the topics of capital structure and real options considered and presents a connection to the question of financial flexibility. The third chapter explains the methodology of this paper and at the same time the simple empirical approach and its results. The fourth chapter provides a summary and outlook on further research approaches that may follow this paper.

\section{Theory and literature overview}

The theoretical financial literature already shows a quite active debate regarding capital structure theory. This is also true for the theory of real options. In this section, both theoretical areas shall be presented in a rough overview and then at the same time a rough overview of the relevant literature will be presented. In the approach of financial flexibility, both theoretical fields are then tied to each other.

The debate on the - perhaps - optimal capital structure began with the contribution "The Cost of Capital, Corporate Finance, and the Theory of Investment" (Modigliani / Miller 1958) by Modigliani / Miller in 1958. In the first version of the so-called MMtheorem it was stated simplified that the capital structure shows no influence on the value of the company and - probably - accordingly not on the real decisions of its management. In fact, the world that Modigliani / Miller described here is not real, as they assumed a world without taxes, transaction costs, bankruptcy costs, an equivalence 


\section{October 19 - 21, 2018 - Munich, Germany}

in borrowing costs for both companies and investors and finally a symmetry of market information. Later Modigliani / Miller explained that the there may be an influence of the capital structure on the value of a company that then might be influenced by imperfections in the financial markets (Modigliani / Miller 1963) - second MMtheorem.

Taking into account the imperfections in the financial markets, the following picture may result. This picture assumes that because of the relatively lower costs of debt and additionally the tax deductibility of interest the value of a company may increase as far as a certain debt to equity ratio is reached. If then the debt to equity ratio increases further, the direct and indirect costs of debt should reduce the equity return and thus value of the company again (Myers 1984). It has to be kept in mind that first the optimal ratio cannot generally be defined and second that this easy explanation does not hold directly for many different and additional assumptions. Resulting, there may be an optimal capital structure (Jensen / Meckling 1976, Harris / Raviv 1991 and others).

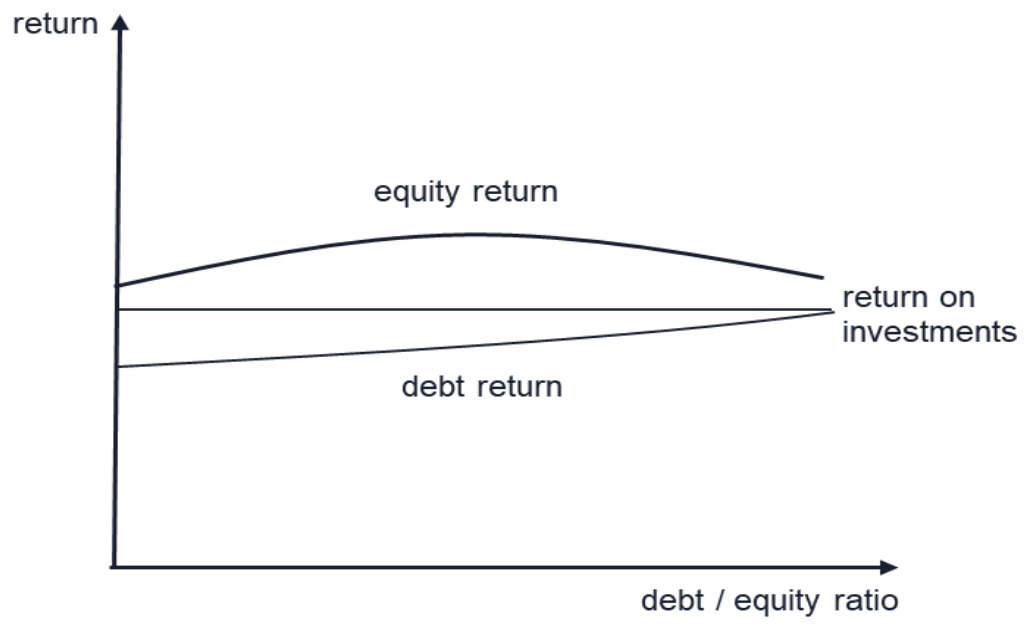

Fig. 1: Return - and value - dependent on the debt / equity ratio

The real world shows, that in fact - somewhere - there is a debt limit; lenders generally will not be willing to go beyond it: 


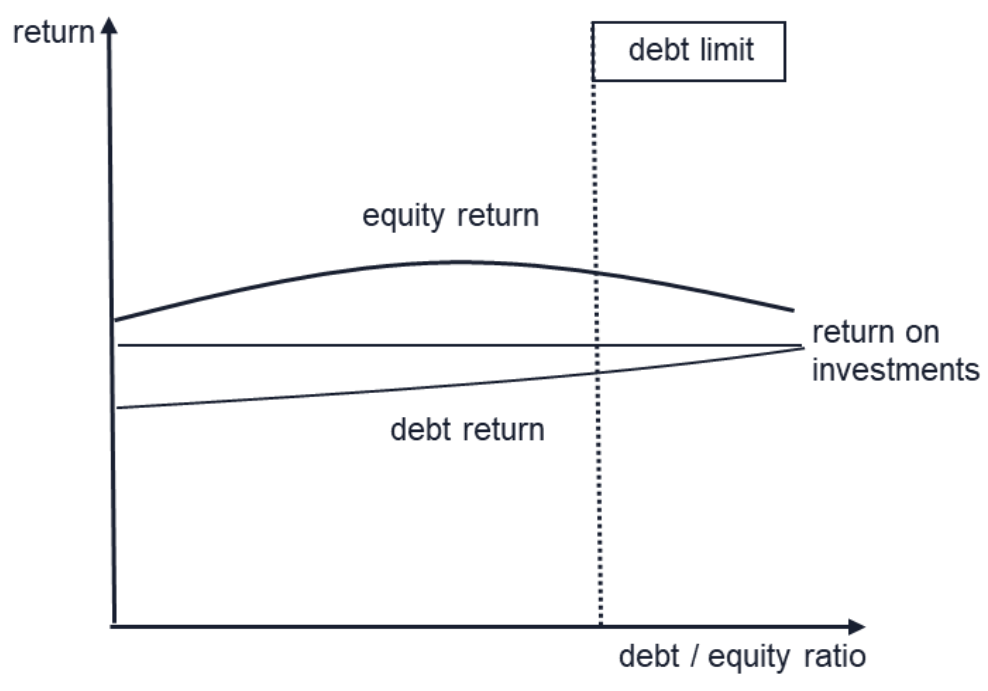

Fig. 2: Debt limit caused by the risk of a higher debt / equity ratio

As already mentioned, in addition to this more or less technical discussion of value, there is also a second part of the capital structure debate. This second part focuses on the question of whether the capital structure of a company can interact with strategic management decisions (Gill / Biger / Mathur 2011, Stulz 1990) - or results (Salim / Yadav 2012). On the one hand, this could mean that certain capital structures lead to certain management decisions. On the other hand, different strategic decisions of a company could correspond to different - optimal - capital structure decisions (Lowe / Naughton / Taylor 1994).

As far as the discussion on real options is concerned, Myers (Myers 1977) was the first to show - under certain circumstances - some similarities between real investments - which are then to be understood as real options - and financial options. The idea of understanding particularly risky investments as real options in an environment of special circumstances was soon supported by Ross (Ross 1978). Trigeorgis and Manson (Trigeoris / Manson 1987) later pointed out that it makes sense to apply the real option approach especially in the case of comparatively risky projects. In short, the idea of real options is the following: There is a specific value in the right to decide - under the circumstances of higher uncertainty - over a period of time whether an investment should be realized or not. If future information later ensures that the investment will be successful, it will be realized and the associated profits achieved. Otherwise, the 


\section{October 19 - 21, 2018 - Munich, Germany}

investment is not realised and only a limited loss is incurred. In general, the following figure illustrates the value of this flexibility. The underlying represents the potential project, the limited investment costs today are to be understood as an option premium (Rams 1999).

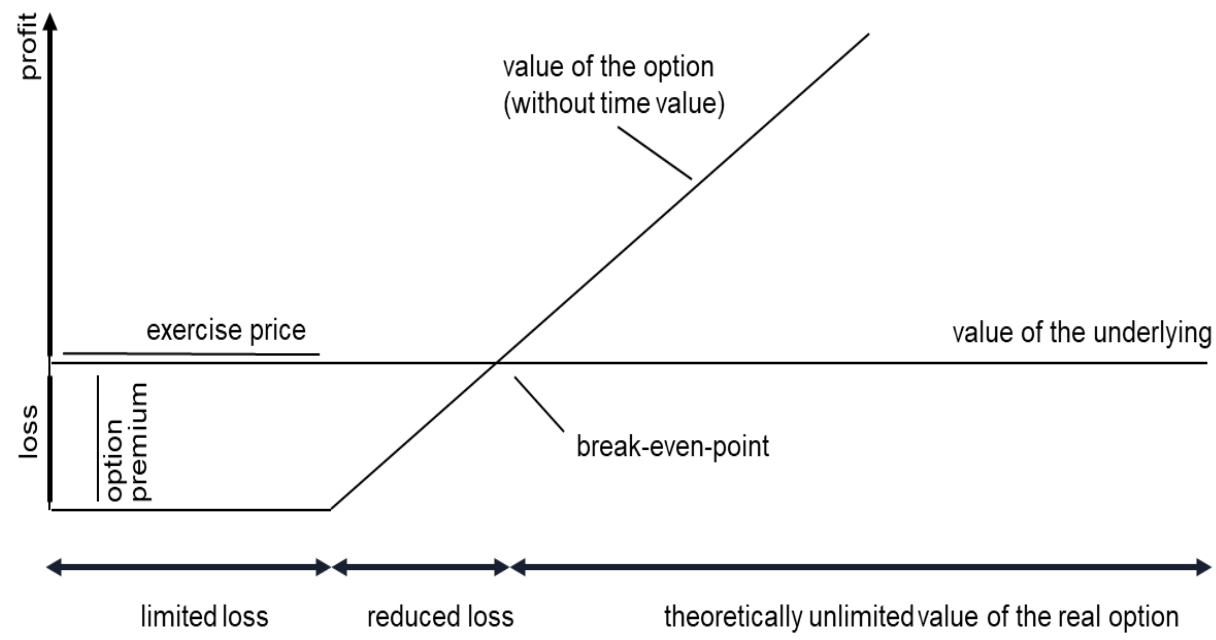

Fig. 3: Illustration of the value of a real option

The research field of financial flexibility can ideally combine the theory of capital structure and the theory of real options. In short, the real options approach essentially assumes that companies operate in an environment of perfect financial flexibility (Gamba / Triantis 2007). The corresponding assumption is that projects that appear profitable automatically find their financing. Since this is - at least not always - true, it seems worthwhile to examine the question of the value of financial flexibility in this paper. Thus, the financial part of the real options - the financial real option - is focused here.

\section{Chosen approach and empirical results}

In general, the capital structure is defined by using only balance sheet items. The capital structure of an enterprise is thus to be understood as the mixture - or structure - 


\section{October 19 - 21, 2018 - Munich, Germany}

of its main capital positions of debt and equity or more detailed including its subcapital positions such as mezzanine capital and others. In real-life situations, a company's capital structure can be very complex and can consist of many sources of capital.

Recent approaches to the capital structure debate take into account financial ratios and their relationship to the company's capital structure (Kisgen 2006, Devos / Rahman / Tsang 2017). The main idea here is to examine whether companies are adjusting their capital structure due to - potential - changes in their credit ratings. Another and relatively new way to use financial measures in the context of the capital structure is to describe them as such (Rams 1918b). This approach then more appropriately takes into account today's understanding of the capital structure in real business life. There, financial managers not only track the debt to equity ratio, but also various specific financial ratios derived from the rating analysis and often are used as debt covenants, too. In this context, the following indicators are quite well established and carefully considered by the financial managers of many companies (Rams 2018a):

- (total or) net debt in relation to EBITDA,

- EBITDA in relation to interest,

- EBIT in relation to interest,

- ratio of debt to equity (or capital / or balance sheet total).

Translated into rating classes, this results in roughly the following scheme (Ganguin / Cochelin 2012):

\begin{tabular}{|c|c|c|c|c|c|c|c|}
\hline Standard \& Poors Peer-Group Industrial, long-term debt & AAA & AA & A & BBB & BB & B & $\mathrm{CCC}$ \\
\hline \multicolumn{8}{|l|}{ S\&P Financial Ratios } \\
\hline EBIT interest coverage $(\mathrm{x})$ & 23,8 & 19,5 & 8,0 & 4,7 & 2,5 & 1,2 & 0,4 \\
\hline EBITDA interest coverage $(x)$ & 25,5 & 24,6 & 10,2 & 6,5 & 3,5 & 1,9 & 0,9 \\
\hline Total debt/EBITDA $(\mathrm{x})$ & 0,4 & 0,9 & 1,6 & 2,2 & 3,5 & 5,3 & 7,9 \\
\hline Total debt/capital (\%) & $12,4 \%$ & $28,3 \%$ & $37,5 \%$ & $42,5 \%$ & $53,7 \%$ & $75,9 \%$ & $113,5 \%$ \\
\hline
\end{tabular}

Tab. 1: Standard \& Poors rating financial ratios - a selection

As it turns out, the debt / equity or debt / capital (= balance sheet total) ratio is only one of the key figures presented above. The point here is to describe the capital structure more precisely with the help of a small set of these figures. As already mentioned, this 


\section{October 19 - 21, 2018 - Munich, Germany}

approach corresponds to current financing practice, as it concentrates on the most important rating indicators and debt covenants. Furthermore, for reasons of simplicity, the following empirical analysis of this paper concentrates on only one of the relevant measures: the most important ratio of debt to EBITDA - the dominant financial measures in this context. This figure is obviously dynamic as it represents the - potential - indebtedness of a company as a multiple of earnings before interest, taxes, depreciation and amortization. Additionally, EBITDA can be understood as an approximation of a cash flow measurement.

Then, the market might agree that 2.5 times EBITDA represents solid indebtedness (about BBB) from a risk perspective. 3.5 times EBITDA can also be accepted, but leads to a higher volume of debt and therefore to a higher risk (about BB) accordingly. In detail, the market today knows and uses specific debt multipliers in various sectors, which then represent the agreed and accepted debt capacity.

Against this background, financial flexibility is then to be understood as the room for manoeuvre that is still open to management within the set limit of the respective EBITDA multiplier. Accordingly, the - open - debt capacity - as financial flexibility is calculated as a financial covenant of 2.5 or 3.5 x EBITDA minus existing financial liabilities. The ratio of EBIT and net income to sales will then be set further in relation to the open debt capacity. Taking into account successful financial strategies of companies, it is assumed that companies that still hold part of their debt capacity open - thus maintaining financial flexibility - may achieve better performance.

The following simple empirical analysis of this paper uses financial figures of a broad selection of German companies from different industries with a turnover between 100 and 1,000 million $€$. The detailed public data sets of around 3,500 companies were analysed. The results of the simple regression analysis are presented below for the years 2012 to 2016 (Rams 2018c): 

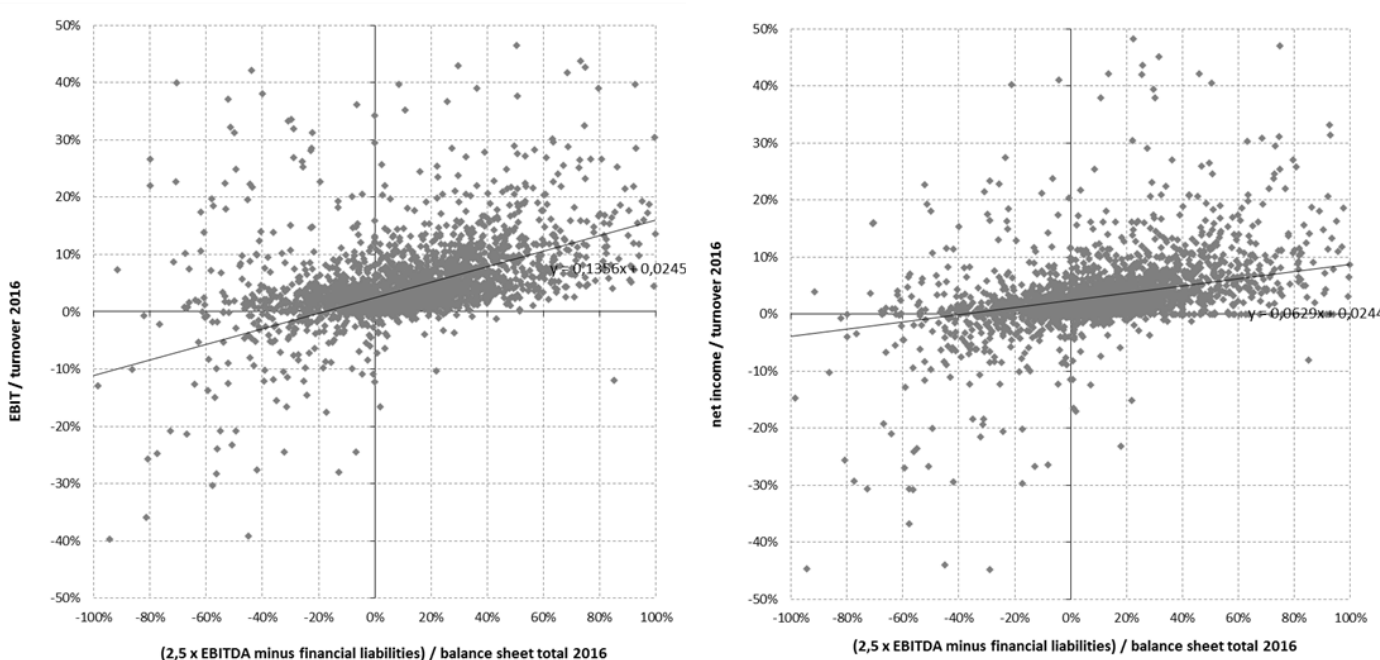

Fig. 4: EBIT and net income / turnover vs. open ( 2.5 covenant) debt capacity 2016

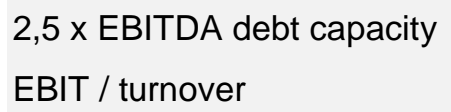

\begin{tabular}{|l|l|}
\hline year & function \\
\hline 2016 & $y=0,1356 x+0,0245$ \\
2015 & $y=0,1265 x+0,0309$ \\
2014 & $y=0,1259 x+0,0031$ \\
2013 & $y=0,1146 x+0,0269$ \\
2012 & $y=0,0865 x+0,0323$ \\
\hline
\end{tabular}

Tab. 2: EBIT / turnover vs. open (2.5 covenant) debt capacity 2012-2016

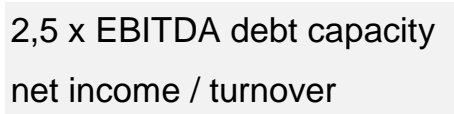

\begin{tabular}{|l|l|}
\hline year & function \\
\hline 2016 & $y=0,0629 x+0,0244$ \\
2015 & $y=0,1036 x+0,0180$ \\
2014 & $y=0,1342 x+0,0107$ \\
2013 & $y=0,1128 x+0,0078$ \\
2012 & $y=0,0832 x+0,0139$ \\
\hline
\end{tabular}

Tab. 3: net income / turnover vs. open (2.5 covenant) debt capacity 2012-2016 

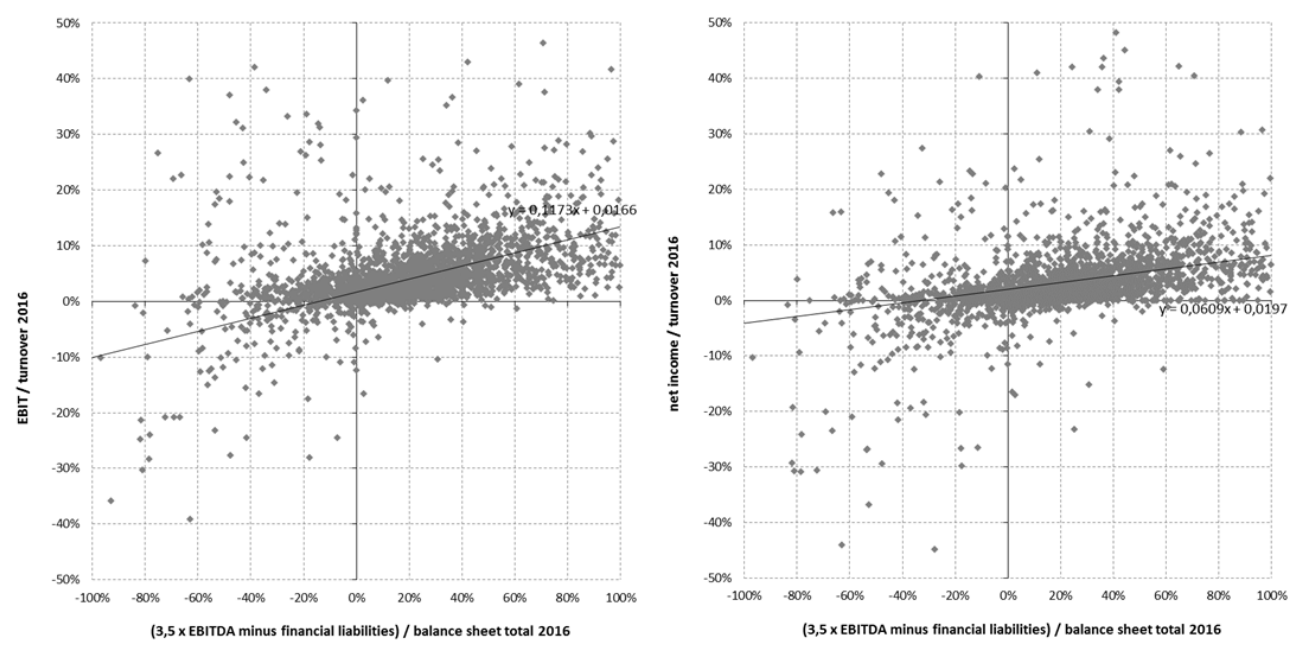

Fig. 5: EBIT and net income / turnover vs. open (3.5 covenant) debt capacity 2016

\begin{tabular}{|l|l|l|}
\cline { 2 - 3 } $3,5 \times$ EBITDA debt capacity & year & function \\
\cline { 2 - 3 } EBIT / turnover & 2016 & $y=0,1173 x+0,0166$ \\
2015 & $y=0,1085 x+0,0214$ \\
2014 & $y=0,1047 x+0,0221$ \\
2013 & $y=0,0972 x+0,0186$ \\
2012 & $y=0,0731 x+0,0263$ \\
\hline
\end{tabular}

Tab. 4: EBIT / turnover vs. open (3.5 covenant) debt capacity 2012-2016

\begin{tabular}{|l|l|l|}
\cline { 2 - 3 } 3,5 x EBITDA debt capacity & year & function \\
\cline { 2 - 3 } net income / turnover & 2016 & $y=0,0609 x+0,0197$ \\
2015 & $y=0,0846 x+0,0112$ \\
2014 & $y=0,1051 x+0,0026$ \\
2013 & $y=0,0915 x+0,0004$ \\
2012 & $y=0,0667 x+0,0088$ \\
\hline
\end{tabular}

Tab. 5: net income / turnover vs. open (3.5 covenant) debt capacity 2012-2016 


\section{HPSCONF}

\section{October 19 - 21, 2018 - Munich, Germany}

The simple regression analysis presented here confirms the formulated assumption that companies show better relative performance if they move within accepted debt limits. The corresponding correlation is stable over the period from 2012 to 2016. It is higher for the ratio concerning the EBIT value than the net profit for the year. There are also minor fluctuations over time. In this way, the respective companies keep their debt capacity open and remain financially flexible for requirements that arise over time. The companies in question keep real financial options open. Thus, they back the values of their other real option.

\section{Conclusion}

The objective of this paper was to analyse the value of financial flexibility by applying an alternative understanding of the capital structure. The value of financial flexibility should be seen as the value of a financial real option. As a result, it has been confirmed that companies that keep their financial flexibility open show relatively better performance ratios. Further research on the question presented appears to be worthwhile. These should continue to reflect the dynamics of the key figures over several periods. In addition, they should include detailed static tests and finally also shed light on the practical reasons for the correlation shown. In summary, the further analysis of financial real options and thus the combination of the capital structure theory with the real option theory appears quite promising.

\section{References}

Devos, E., Rahman, S., Tsang, D., 2017. "Debt covenants and the speed of capital structure adjustments", Journal of Corporate Finance, Vol. 45, pp. 1-18.

Gamba, A., Triantis, A.J., 2008. "The value of financial flexibility”, Journal of Finance, 2008, vol. 63, issue 5, pp. 2263-2296.

Ganguin, B., Cochelin, P., 2012. “Standard \& Poor's Corporate Ratings Methodology and Rating Trends", Presentation à 1'AF2I of 24th October 2012. 


\section{October 19 - 21, 2018 - Munich, Germany}

Harris, M., Raviv, A., 1991. "The theory of capital structure", Journal of Finance 46, pp. 297- 356.

Jensen, M.C., Meckling, W.H. 1976. "Theory of the firm: managerial behavior, agency costs and ownership structure”, Journal of Financial Economics 3, pp. 305360.

Kisgen, D., 2006. "Credit ratings and capital structure", The Journal of Finance, 61(3), pp. 1035-1072.

Lowe, J., Naughton, A. and Taylor, P., 1994. “The Impact of Corporate Strategy on the Capital Structure of Australian Companies", Managerial and Decision Economics, Vol. 15, pp. 245-257.

Myers, St. C., 1977. "Determinants of corporate borrowing”, Journal of Financial Economics 5 (1977), pp. 147-175.

Myers, St. C., 1984. "Finance Theory and Financial Strategy", Interfaces, Vol. 14, No. 1, 1984, pp. 126-137.

Modigliani, F., Miller, M.H., 1958. "The Cost of Capital, Corporate Finance, and the Theory of Investment", American Economic Review, Vol. 48, pp. 261-297.

Modigliani, F., Miller, M.H., 1958. "Corporate Income Taxes and the Cost of Capital: A Correction”, American Economic Review, Vol. 53, pp. 433-443.

Rams, A. 1999. "Realoptionsbasierte Unternehmensbewertung”, FinanzBetrieb : FB ; Zeitschrift für Unternehmensfinanzierung und Finanzmanagement, Vol. 1.1999, 11, p. 349-364.

Rams, A., 2018a. "Strukturierte Finanzierungen - Bedeutung und Einsatz von Covenants", Presentation at Frankfurt School of Finance and Management, Frankfurt, May 2018.

Rams, A., 2018b. "Debt Capacity and Company Performance", Proceedings of The IRES International Conference, Philadelphia, USA, 28th-29th July 2018, pp. 
3-8.

Rams, A., 2018c. "Financial covenants and company performance: a capital structure approach, 2018 WEI International Academic Conference Proceedings, Westeasterninstitute, New York, $10^{\text {th }}-12^{\text {th }}$ August 2018, pp. 323-340.

Salim, M. Yadav, R., 2012. "Capital Structure and Firm Performance: Evidence from Malaysian Listed Companies”, Procedia - Social and Behavioral Sciences, Vol. 65, pp. 156-166.

Stulz, R., 1990. "Managerial discretion and optimal financing policies," Journal of Financial Economics, 1990, Vol.26, pp. 3-27.

L. Trigeorgis and S. P. Mason, "Valuing Managerial Flexibility," Midland Corporate Finance Journal, Vol. 5, No. 1, 1987, pp. 14-21. 